\title{
Funerary rites in a Neolithic nomad community in Southeastern Arabia: the case of al-Buhais 18
}

\author{
Roland de Beauclair \\ Institut für Ur- und Frühgeschichte und Archäologie des Mittelalters, Universität Tübingen \\ roland.de.beauclair@student.uni-tuebingen.de
}

\begin{abstract}
Al-Buhais 18 is a Neolithic site in the United Arab Emirates. It consists of a graveyard with more than 420 individuals, an ancient spring, and a campsite. It is interpreted as a central place for a group of mobile herders in the $5^{\text {th }}$ millennium BC. More than 24000 ornamental objects have been found, many of them in a secure funerary context, making it possible to reconstruct ornamental ensembles, and shedding light on specific rules concerning the way jewellery was worn by different sub-groups of the population. Based on these observations, some hypotheses are developed on the intentions and beliefs structuring mortuary practices and the role of jewellery within these rites. Finally, questions of continuity and change in mortuary practices can be addressed by comparing alBuhais 18 with other, younger, sites in the region.

IZVLEČEK - Al-Buhais 18 je neolitsko najdišče v Združenih Arabskih Emiratih. Najdišče obsega grobišč z več kot 480 grobovi, taborom in izvirom vode. Najdišče je interpretirano kot centralni tabor mobilnih živinorejcev v 5. tisočletju BC. Najdenih je bilo 24000 okrasnih predmetov. Mnogi so bili odkriti v grobovih. Mogoče je rekonstruirati okrasne zbire in prepoznati pravila, ki so veljala pri nošnji okrasa pri različnih skupinah. Predstavljamo nekaj razmislekov o pomenu in vlogi okrasja pri pogrebnih praksah. $S$ pomočjo primerjave najdišča al-Buhais 18 z mlajšimi najdišč predstavljamo oceno kontinuitete pogrebnih praks $v$ regiji.
\end{abstract}

KEY WORDS - Neolithic; Arabia; burials; personal ornaments; mortuary practices

\section{Introduction}

Personal ornaments offer a wealth of information for archaeologists. They can be analyzed in terms of production technique, provenance of raw materials or object typology. But it is also evident that ornamental objects are used in a social context, as a means of communication - for example as exchange goods or in rituals. Of course, there are many more possible meanings of jewellery, and several concepts may have been important simultaneously, a fact that has been described as the "caractère polysémique" (Vanhaeren 2002.7) of jewellery.

The Neolithic site of al-Buhais 18, United Arab Emirates, provides an excellent opportunity for investigations on several of these levels. After an introduc- tion to the site and a presentation of the ornamental objects, it is my aim in this paper to show how information related to personal ornaments can be used to reconstruct aspects of funerary rites. Also, data on jewellery and burial practice is used to place the occupation of the site in a regional and chronological context.

\section{The site}

The Neolithic graveyard and settlement site of alBuhais 18 (BHS18) is situated on the Oman Peninsula at a distance of about $60 \mathrm{~km}$ from both the Arabian Gulf and the Gulf of Oman (Fig. 1). The site lies at the eastern foot of Jebel al-Buhais, just north of 
al-Madam in the Emirate of Sharjah, United Arab Emirates. Jebel al-Buhais is part of a hill range running parallel to the Oman Mountains, separating the sand dunes in the west from a large and relatively fertile floodplain and then the Mountains in the east.

Al-Buhais 18 was discovered in 1995 by archaeologists from the Sharjah Directorate of Antiquities, under the direction of Dr. Sabah Jasim. From 1996 to 2004, it was excavated in annual campaigns as a joint project of the Directorate of Antiquities and the University of Tübingen, Germany, co-directed by Hans-Peter and Margarethe Uerpmann (Jasim et al. 2005; Uerpmann et al. 2006a).

Radiocarbon dates indicate that al-Buhais 18 was frequented from about 5200 to $4000 \mathrm{BC}$ (de Beauclair et al. 2006.175; Uerpmann et al. 2000.231; Uerpmann et al. 2006b.90). The abandonment of the site would thus coincide with the end of the major moist phase of the Early Holocene (Uerpmann 2003).

The site can be divided into several areas. The central feature is the graveyard. On a relatively small area of about 12 by 15 meters, more than 420 individuals have been recovered. Directly adjacent to the graveyard in the east, there is a midden of limestone rubble mixed with stone artefacts and animal bones. As many of the stones show signs of heating, the area is thought to be related to food processing. The last important structure on the site is an ancient spring a few meters up the slope of the hill. Uranium/Thorium dating of the sinter deposits has not given satisfactory results yet, but it seems very probable that the spring was active during the time of occupation of al-Buhais. Its drying up may have led to the abandonment of the site.

A great number of animal bones have been recovered, almost exclusively from domestic animals sheep, goats, cattle. It was a big surprise to find a Neolithic economy in south-eastern Arabia at such an early date. The age profile of animal bones suggests that the site was used only seasonally, pointing to a nomadic lifestyle. The culling of young ani-
The site is interpreted as a central place for a population of mobile herders, used seasonally over hundreds of years (Jasim et al. 2005; Uerpmann and Uerpmann 2000.47-48; Uerpmann et al. 2000. 232; Uerpmann et al. 2006b.99-100). They would have come to Jebel al-Buhais to graze their herds in spring, to bury their dead and perhaps for clan reunions. Winter may have been the time to exploit the coasts, where a considerable number of shell middens attest to the presence of Neolithic populations. Summer or autumn camps may have been located in the cooler mountain regions of Oman, where pasture was more likely to be available. However, even though ophiolite pebbles link the al-Buhais population to the mountains, we do not have any information about specific localities or the seasonal position of this occupation. All in all, it has to be said that we still know only very few sites. Further discoveries can be expected, which probably will make it necessary to re-adjust these hypotheses.

\section{Burial practices}

A variety of burial types is present. There are single and multiple interments, which can also be grouped into primary and secondary ones. A detailed study of burial practice and physical anthropological evidence has been carried out by H. Kiesewetter (2006). From a total of 420 burials recorded up to the year 2004 , information on burial type is available in 280 cases (Tab. 1). Primary burials occur in 115 cases. 
There, the body was buried shortly after death, without prior manipulations of the skeleton. The bones were still articulated and therefore have been found in the correct anatomical position. The bodies were buried in a flexed position, usually lying on the right side, but sometimes also on the left side (Fig. 2). Primary burials are most often oriented along an eastwest axis, with the cranium to the east (Fig. 3). Due to right/left sidedness, facial orientation is more variable, but still predominantly to the north.

Secondary burials are more frequent, with $165(60 \%)$ cases. Most often, they consist of only the skull and some long bones arranged in a small pile, often with the skull laid on top (Fig. 4). Sometimes, only the skull was buried. Usually, several individuals are interred together. The primary decomposition of the dead bodies must have taken place prior to their burial at al-Buhais 18. As a special case of secondary burials, there are eight semi-articulated, mummy-like skeletons. In these cases, most of the joints must still have existed at the time of reburial, but the whole body was compressed, and some joints were disarticulated or overstretched in an unnatural way.

Secondary burials are interpreted as pertaining to group members who had died at a point in the yearly nomadic cycle, when the group was moving or staying at some place other than Jebel al-Buhais. These individuals must have been buried locally in a first phase. After some time, their bones were exhumed in part or in total, in order to rebury them at the graveyard of BHS 18 . We can only guess what

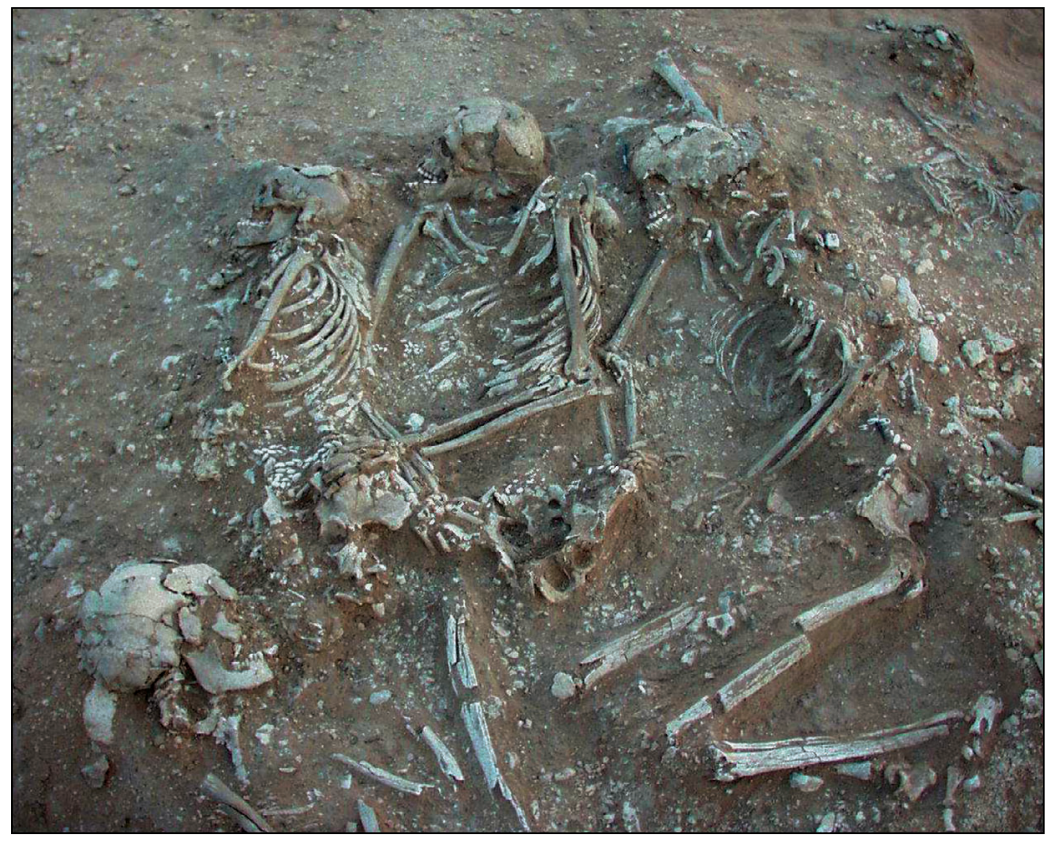

Fig. 2. Primary burial of individuals $B X, B Y, H S$.

\begin{tabular}{|lc}
\hline Primary burials & 115 \\
\hline Right side & 86 \\
\hline Left side & 28 \\
\hline Secondary burials & 165 \\
\hline Skull deposits & 29 \\
\hline Bone deposits & 128 \\
\hline Semi-articulated skeletons & 8 \\
\hline Undetermined & $\mathbf{1 4 0}$ \\
\hline Total & $\mathbf{4 2 0}$ \\
\hline
\end{tabular}

\section{Tab. 1. Burial types.}

made the site of al-Buhais 18 so singular - perhaps its importance is related to the spring, or to the view over the al-Madam plain with the rising sun behind the Oman Mountains. In any case, it is clear that it was important to the group to place its ancestors in this specific location. The two-stage burial indicates that the group spent part of its nomadic cycle at distances too far from al-Buhais to permit an immediate return to the site for an interment. Also, it may not have been possible for the group to carry the whole corpse with them along the nomadic routes until it eventually was time to head for Jebel al-Buhais again. This model also explains the high frequency of multiple interments - those who had died in a certain period were reburied together in one ceremony. There are some indications as to where some of the first burials took place. In the semi-articulated skeleton $\mathrm{TG}$, sediment of the first burial location is still mingled with the bones: pebbles of grey-green ophiolite indicate that the body had been buried in a Wadi river bed somewhere in the Oman Mountains, the closest location where these pebbles occur naturally.

Interestingly, the proportion of secondary burials is higher in males than in females, and higher in mature than in younger individuals. Should this indicate that men spent more time away from al-Buhais 18 than women? And what does that mean for old people? For the moment, these questions must remain open.

\section{The ornamental objects}

More than 24000 objects of presumed ornamental purpose were recorded during the excavations (de Beauclair 2005; de Beau- 
clair in press; de Beauclair et al. 2006; Kiesewetter et al. 2000). They can be divided into pierced molluscs, beads and other ornamental objects (Tab. 2).

\section{Pierced molluscs}

The mollusc species list shows that gastropods are very dominant. The important species are Ancilla $c f$. farsiana, Engina mendicaria, Polinices mammilla, Anachis fauroti, an unidentified species of the Marginellidae family, and Planaxis niger. Bivalves are represented by some Venerids. There are also an important number of pearls. Interestingly, there is a concentration on relatively few species. Ancilla alone constitutes $75 \%$ of all molluscs. What is also striking is the absence of Dentalium, which was used at many other sites of the period. Additionally, there was a preference not only for specific species, but also for certain sizes. Both Ancilla and Engina show a size distribution with two peaks. Further analysis of the small and the big subgroup shows that they were in fact used differently.

With only very few exceptions, every shell is perforated. The position and method of the perforation is formalized for every species: for instance, Ancilla snails are almost always perforated by cutting away the apex, whereas in Polinices the hole is located on the flat part of the body and executed by picking.

\section{Beads}

When it comes to beads with an artificial shape, also very few types are quantitatively important. Disc beads are most numerous (>16 000). Their diameters range from 1.7 to $18.2 \mathrm{~mm}$, but sizes between 3 and $5 \mathrm{~mm}$ are most common. They are usually made of a whitish or orange shell material. Sometimes an internal layering of orange and white is visible. They make up $2 / 3$ of all ornamental objects. Next in quantity are tubular beads. They are made of whitish shell or dark grey soft-stone, probably some mixture of serpentinite and other minerals. These two materials occur in almost equal numbers. The tubular beads are up to $31.6 \mathrm{~mm}$ long. The diameter of the perforation is always less than $3 \mathrm{~mm}$, even less in the middle of the pieces. No suitable tools for the production of these beads have been found on the site or, for that matter, in the whole region. I therefore believe that these

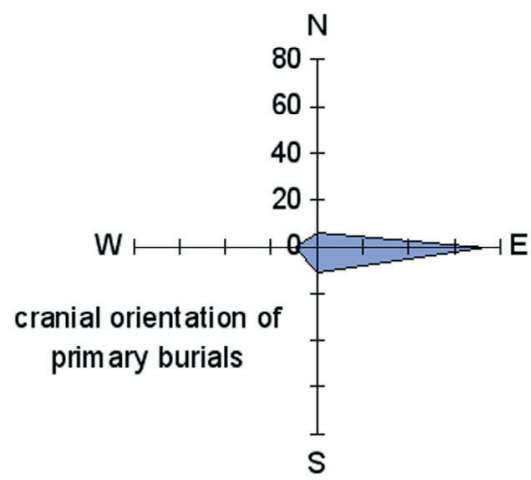

Fig. 3. Orientation of primary burials.

beads - and probably others - were imported. Barrel shaped beads constitute another important group (114 pieces). Here, a wide variety of materials was used, mainly shell and limestone, but also serpentinite and other stones. Light colours dominate. Next, oval beads have to be mentioned. There are 40 examples of this type. The majority are made of shell and limestone. What is interesting about them is the fact that only two are perforated completely. The rest have two depressions or short bore-holes at either end, but the holes do not meet. One might think of these as unfinished objects, but a considerable number have been found in burials in positions that indicate their having been used as jewellery. Notably, they were found as single beads on the upper lip or near the earlobes. Other bead types are less frequent: they include spherical, conical and rhomboid beads. Their shapes do not seem so well defined, and material seems to be more important (for instance, carnelian).

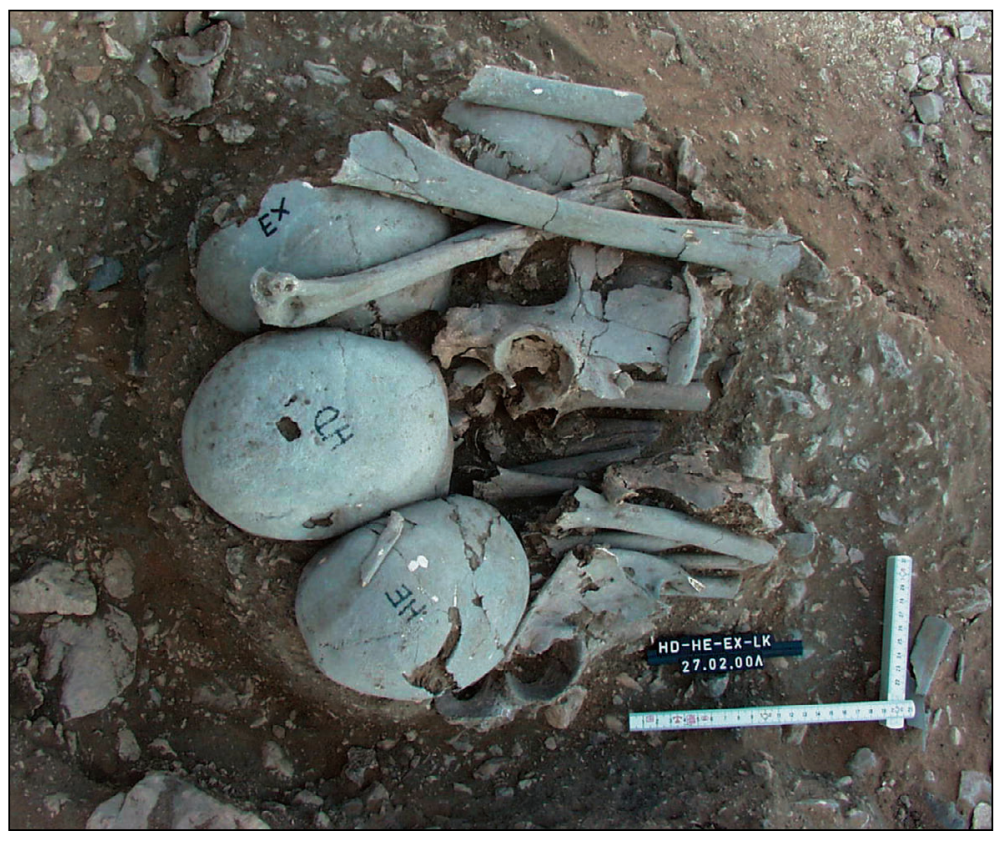

Fig. 4. Secondary burial of individuals $\mathrm{HD}, \mathrm{HE}, \mathrm{EX}, \mathrm{LK}$. 


\begin{tabular}{|c|c|}
\hline type & n \\
\hline Ancilla cf. farsiana & 3902 \\
\hline Engina mendicaria & 524 \\
\hline Polinices mammilla & 423 \\
\hline Anachis fauroti & 101 \\
\hline Marginellidae & 74 \\
\hline Planaxis niger & 56 \\
\hline Nerita adenensis & 13 \\
\hline Pyrene cf. propinqua & 9 \\
\hline Conus & 7 \\
\hline Mitrella blanda & 7 \\
\hline Veneridae & 67 \\
\hline pearls & 62 \\
\hline subtotal molluscs & 5245 \\
\hline disc beads & 16654 \\
\hline tubular beads & 2218 \\
\hline cylindrical beads $\mathrm{w}$. lateral perforation & 2 \\
\hline barrel-shaped beads & 114 \\
\hline oval beads & 40 \\
\hline spherical beads & 20 \\
\hline conical beads & 10 \\
\hline rhomboid beads & 4 \\
\hline subtotal beads & 19051 \\
\hline leaf-shaped pendants & 7 \\
\hline other pendants & 2 \\
\hline elongated shell object & 1 \\
\hline earring & 2 \\
\hline ring & 1 \\
\hline 'buttons' & 2 \\
\hline subtotal other ornamental objects & 15 \\
\hline total & 24311 \\
\hline
\end{tabular}

Tab. 2. Ornamental object types.

Finally, some other ornamental objects have been found, most importantly a number of leaf-shaped pendants made of mother-of-pearl, and Conus shell and soft-stone pendants.

All in all, the close relationship of the al-Buhais population to the sea is very evident. Engina and Planaxis niger point to the Omani coast, but this naturally does not imply that the Arabian Gulf coast was not used. Much work still lies ahead concerning the reconstruction of nomadic mobility.

\section{How ornamental objects were worn}

The importance of the jewellery from al-Buhais lies not only in the mass of material, but also in the fact that a large portion, almost 70 percent, was found within a burial context. Secondary burials have yiel- ded very little jewellery, and not in any recognizable anatomical context. The analysis of how jewellery was worn is therefore based on primary burials. As these results have been presented in more detail elsewhere (de Beauclair et al. 2006), only a brief overview is given here.

As a first step, different types of ornamental ensembles and their characteristic features were identified. For example, head decorations are very common, either covering the whole neurocranium or only forming a headband. Two different styles were observed: a preference for disc and tubular beads, or the dominance of Ancilla shells. Generally, the objects are relatively small.

Earrings: there are eight cases of a semi-perforated oval bead being placed at the earlobe. An equal number of individuals had what I term a facial decoration, that is a single bead on the maxilla, placed between the upper lip and the nose. The bead types are diverse, but the preferred material is carnelian. Some have incomplete perforations.

Necklaces were very common, occurring in 34 cases. The most important bead type is tubular, which occurred in 27 individuals. Black and white beads are often used in an alternating pattern. Barrel shaped beads make up the second most popular style of necklace.

The hip area, again, was an important place for jewellery, for both sexes. In several cases, neat parallel rows have been observed. The objects were probably sewn onto a belt or onto the lower hem of shirts. There is a very strong preference for big $A n$ cilla shells. On the other hand, the total absence of Engina mendicaria is also remarkable. Again, a second style is also popular, involving a mix of disc and tubular beads.

Bracelets are also common (28 cases, 21 individuals). They occur in three styles: one with tubular beads, one mainly with disc beads, and one consisting only of Ancilla shells.

Some general observations:

- Any piece of jewellery consists only of a very limited number of bead and shell types, and not every bead type was considered appropriate for every anatomical position. For instance, carnelian beads and pearls, both of which could be considered very valuable, were concentrated in the head area. 
- There is an apparent dualism of pierced gastropods on one side and tubular beads on the other in several types of ornamental ensemble, including headdresses, hip decorations and bracelets.

- Finally, garment trimmings need to be mentioned here. Judging from their positions, headdresses, chest and hip decorations and, perhaps, also elbow decorations, may have been sewn onto pieces of clothing. These are the same places at which gastropods tend to occur frequently, so arguably, trimming was deemed more suitable for pierced shells (and disc beads) than for other beads.

In the second step of analysis, I tried to find typical combinations of different ornamental ensembles. The goal was to reconstruct aspects of the prehistoric dress code or garb for the population as a whole and for subgroups. This was done with the help of a contingency analysis. The results of this analysis were not very clear. Almost any combination of ornamental ensembles was possible.

The results for different subgroups are more interesting.

Gender differences are only minor. Apparently, the society did not emphasise this distinction. One of the observed differences concerns facial decorations: beads on the upper lip have been recorded for five women and two men. The women's beads are all perforated and all made of carnelian, except for one pearl. The men's beads are both only partially perforated, which implies a different mechanism for holding the beads in place. However, this distinction is not statistically significant.

Age clearly was a more important factor in determining the burial garb than gender:

- Children's burials were as rich as those of adolescents or adults. Mature individuals, on the other hand, were rarely and very poorly decorated (Figs. 5 and 6).

- The preferred bead types for children were disc and tubular beads. Namely, necklaces made of tubular beads are typical of children's and adolescents' burials. Children also feature a high number of disc bead bracelets and hip decorations with disc and tubular beads.
- Pierced molluscs, on the other hand, were only popular for adults and especially mature individuals, corresponding to a decreasing importance of disc and other beads.

- Shell size also depended on the age of the deceased: small varieties were preferred for children and youths. Small and big shells are balanced in adults between 20 and 40 years, and big specimens were preferred for older people.

\section{The role of jewellery in burial rites}

The data presented above makes it possible to formulate some ideas on the function and importance of jewellery in the course of the funerary rites or beyond.

- First of all, we do not know whether the use of jewellery for the dead corresponded to its use in the living community. The low number of ornamental objects outside the graveyard area rather suggests that jewellery was not worn in everyday life. Otherwise, more broken and lost objects should have been found. Polinices shells, however, do occur in relatively great number. So maybe they are part of a more simple ornamental style for everyday use.

- Second, the main function of jewellery probably wasn't the display of acquired status or wealth. If this were the case, children's burials should not be as rich as they are. Of course, if status was inherited, other mechanisms may be relevant.

- The differences in jewellery between different age groups and the poorness of mature individuals furthermore indicate that jewellery was not a per-

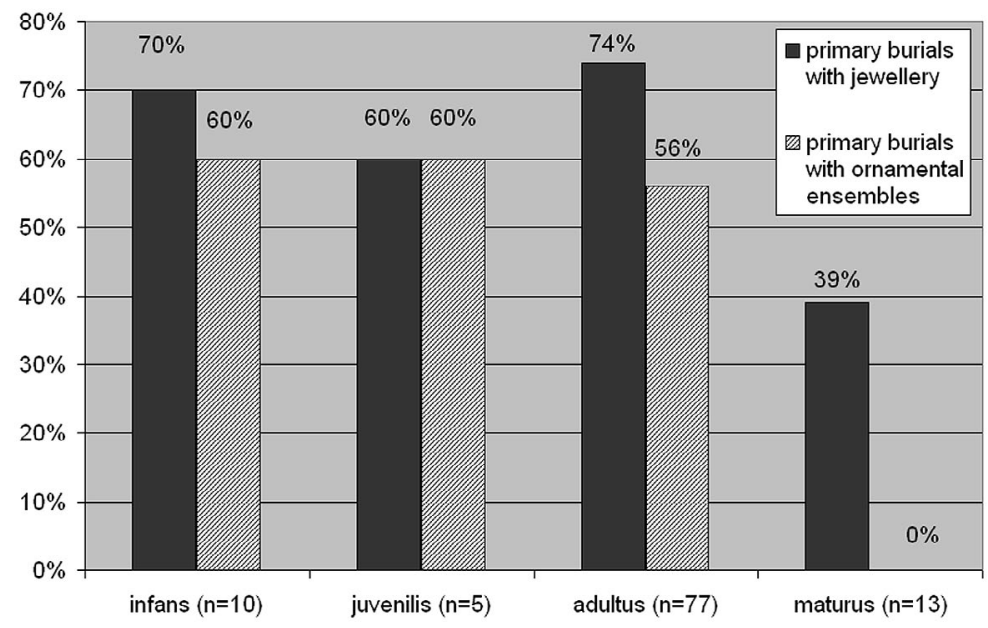

Fig. 5. Jewellery frequency by age. 
sonal possession; it was not something individuals accumulated in the course of their lives. If this were the case, adults and mature bodies should have the same equipment as children, plus some more.

- Finally, there is the absence of jewellery in secondary burials. After the first stage of burial, jewellery was obviously no longer important. If the aim was to document wealth, jewellery could have been added to the bone piles of the secondary burials as well.

- All this leads me to think of jewellery as having its place in the process of burial, in some "rite de passage" (Van Gennep 1986.142-159). Community members would decorate the dead for the passage. After completion of the burial process, jewellery may have lost its importance. This would explain the absence of jewellery in secondary burials. Finally, the age differences need to be explained. This is a difficult question, and many hypotheses could be brought forward. I only want to mention one idea, evidence for which can be found in the ethnographic record (Hertz 1907. 134): I could imagine that the untimely death of a child or young adult would have caused greater anxiety and required a more lavish burial than the death of an old person whose life had been accomplished.

\section{Continuity and change in funerary rites}

There are only a small number of contemporary sites in the region which can be used to compare the burial rites of al-Buhais 18 . A very promising site was

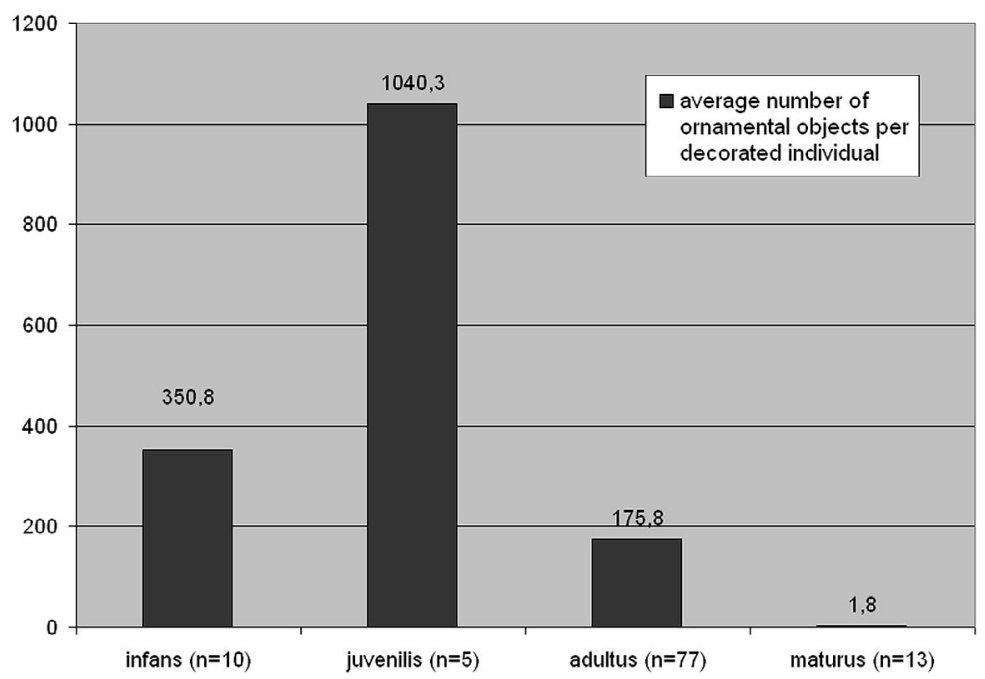

Fig. 6. Number of ornamental objects per decorated individual by age. discovered by the al-Buhais excavation team in 2006, only a few kilometres north of BHS 18, at the foot of Jebel Fayah (Kutterer and de Beauclair in press). It is called Fayah NE15. A dwelling area with fireplaces, flint artefacts, faunal remains and the burials of three individuals have been recovered so far. The jewellery associated with the burials resembles BHS18, and places the site in the Neolithic period. The similarities concerning ornamental objects are very striking, but there are some differences nonetheless. It remains open to discussion whether these reflect different temporal settings or the need of two contemporary groups to distinguish themselves from one another. There are also some shell middens on the coast of the Arabian Gulf which might be contemporaneous. One, Umm al-Qaiwain 2 'UAQ2', has yielded burials. It has been excavated under the direction of C. Phillips. Only a preliminary report is available at present (Phillips 2002). Forty-two individuals have been found in the cemetery. Nine skeletons were articulated, all placed in a flexed position, and most of them facing southeast. The others are assumed to have been disturbed by later burials. It is unclear whether secondary burials similar to BHS 18 were also considered as an interpretation. A number of ornamental objects were found at UAQ2. Some may be similar to BHS 18, but there are also marked differences: for instance, there are bitumen beads which have no parallel at BHS 18. A rounded stone pendant differs in material and style from the pointed mother-of-pearl pendants at BHS 18. The presence of composite bracelets made of shell plates, well attested at UAQ2, is not secure at BHS 18.

So, even though the burial types seem similar, the case is not clear for the jewellery. It remains an open question how close the relationship between the two sites was.

Another shell midden site with settlement and graveyard areas is Ra's alHamra 5 (RH5). The site was excavated in the Eighties by the Italian Archaeological Mission to Oman and Baluchistan (Salvatori 1996; Santini 2002). It is located not far from Muscat on the coast of Oman. The graveyard is dated to $c .3800$ to 3300 BC (Biagi 1994), thus being younger than BHS 18. At least 170 individuals were discovered, some of them in a flexed position, mostly on the right side; others were in bone piles, which are interpreted as secondary 
burials. Both types show a northeast-southwest orientation, with the skull to the North-East. The graves often have stone coverings and contain animal bones, e.g. of marine turtles. Apart from the last characteristic, the similarities to BHS 18 are striking.

Grave goods were mostly personal ornaments. Among these, several types of shell pendant are present: there are laurel-leaf shaped pendants, often decorated with diagonal incisions along the edges: drop shaped ones, which in addition to incisions, feature a pattern of engraved dots; and finally, there are pendants in the shape of a shark tooth. Only the leaf shaped pendants have a resemblance to objects from BHS 18, although the latter lack the incisions. Cylindrical beads apparently occur mainly in necklaces. They are made of dark soapstone and shell, and are often arranged in an alternating pattern similar to BHS 18 , but seem to be relatively short in comparison (Coppa et al. 1985.plate 3). Interestingly, pierced gastropods do not play an important role at RH5. Only one headdress of Nassarius sp. is mentioned. Pearls are also rare. Other ornamental objects include an important number of composite shell bracelet elements, as well as soapstone earrings and bone pins. None of these can serve as a link to the BHS 18 graveyard. Finally, some oval soapstone beads and cylindrical beads made of bird bones and Dentalium $s p$. are noteworthy. They are rare and occur only in a certain part of the site (area 43), thus appearing to be intrusive.

The best link between the jewellery from BHS 18 and RH5 may be seen in the tubular beads, and especially in the alternating arrangement of these beads, as well as in the presence of leaf-shaped pendants. On the other hand, there are ornamental objects which lack any parallel at BHS 18, while conversely, certain bead types from BHS 18, like the massive barrel shaped beads, do not occur at RH5. The same can be said for the most common gastropod species, Ancilla cf. farsiana. Both populations made use of different resources and probably of different mollusc habitats. In the end, the observed parallels in burial types, especially skeletal position and orientation, document a relatively widespread homogeneity - spatially and chronologically - in these questions in the Neolithic of the Oman Peninsula (Charpentier et al. 2003). The importance of personal ornaments as grave goods was also a widespread phenomenon. Seemingly, jewellery types were subject to more local variability, but certain aspects also show much continuity.

\section{Conclusion}

The observed continuities from BHS 18 to RH5 in burial style and jewellery are the starting point for some thoughts on the end of occupation at BHS 18. The abandonment of the site around $4200 \mathrm{BC}$ is seen as the result of a major climatic deterioration around this time. Increased aridity had dramatic effects in Southeast Arabia. Probably, the drying up of the spring at Jebel al-Buhais is part of this development. Apparently, it was no longer possible to maintain the mobile herding economy with seasonal stays in the interior of the Oman Peninsula. The coasts could be considered possible areas of retreat for the desert pastoralists. On the Arabian Gulf coast, however, the depopulation is only delayed for some time. The situation is different on the Omani coast, where shell midden sites are well attested for the $4^{\text {th }}$ millennium $\mathrm{BC}$. This can be explained by a more favourable geomorphology, which not only assures fresh water from the wadi beds in the nearby mountains, but also leads to a more diverse environment, potentially richer in resources. Consequently, the relocation of the al-Buhais population to this coast has to be considered a very likely possibility.

In this context, the observed similarities in jewellery and burial style between BHS 18 and $\mathrm{RH} 5$ are an important indication of cultural continuity. Several hundred years lie between the end of BHS 18 and the beginning of the $\mathrm{RH} 5$ graveyard, so that a direct continuation of jewellery style would be surprising, even more because the population experienced major changes in their subsistence economy and activity areas. It is natural that new preferences in ornamental objects developed. On the other hand, some traditions remained alive, such as the fondness for leaf-shaped shell pendants and tubular beads in contrasting colours, and help us trace the fate of the al-Buhais desert nomads. 


\section{REFERENCES}

BIAGI P. 1994. A radiocarbon chronology for the aceramic shell-middens of coastal Oman. Arabian Archaeology and Epigraphy 5: 17-31.

CHARPENTIER V., MARQUIS P., PELLÉ É. 2003. La nécropole et les derniers horizons Ve millénaire du site de Gorbat al-Mahar (Suwayh, SWY-1, Sultanat d'Oman): premiers résultats. Proceedings of the Seminar for Arabian Studies 33: 11-19.

COPPA A., MACCHIARELLI R., SALVATORI S., SANTINI G. 1985. The Prehistoric Graveyard of Ra's al-Hamra (RH5): (A short preliminary report on the 1981-83 excavations). Journal of Oman Studies 8: 97-102.

DE BEAUCLAIR R. 2005. Seashells in the Desert. A Study of Personal Adornments from the Neolithic Graveyard of al-Buhais 18, Sharjah, U.A.E. Master thesis, Eberhard Karls Universität Tübingen.

in press. La parure funéraire de la nécropole néolithique de Jebel al-Buhais 18 (Émirats Arabes Unis). Préhistoire Anthropologie Méditerranéennes 14.

DE BEAUCLAIR R., JASIM S. A., UERPMANN H.-P. 2006. New results on the Neolithic jewellery from al-Buhais 18, UAE. Proceedings of the Seminar for Arabian Studies 36: 175-187.

HERTZ R. 1907. Contribution à une étude sur la représentation collective de la mort. L'année sociologique 10: 48137.

JASIM S. A., UERPMANN H.-P., UERPMANN M. 2005. Neolithic Life and Death in the Desert - 8 seasons of excavations at Jebel al-Buhais. In P. Hellyer and M. C. Ziolkowski (eds.), Proceedings of the $1^{\text {st }}$ Annual Symposium on Recent Palaeontological \& Archaeological Discoveries in the Emirates, Al Ain 2003. Al Ain: Zayed Center for Heritage and History: 29-36.

KIESEWETTER H. 2006. Analyses of the Human Remains from the Neolithic Cemetery at al-Buhais 18 (Excavations 1996-2000). In H.P. Uerpmann, M. Uerpmann, S. A. Jasim (eds.), Funeral Monuments and Human Remains from Jebel al-Buhais, vol. 1. The Archaeology of Jebel alBuhais. Sharjah, United Arab Emirates. Tübingen: Department of Culture and Information, Government of Sharjah, U.A.E./Kerns Verlag: 103-380.

KIESEWETTER H., UERPMANN H.P., JASIM S. A. 2000. Neolithic jewellery from Jebel al-Buhais. Proceedings of the Seminar for Arabian Studies 30: 137-146.
KUTTERER A. U., DE BEAUCLAIR R. in press. FAY-NE15 Another Neolithic graveyard in the Central Region of Sharjah Emirate? Arabian Archaeology and Epigraphy.

PHILLIPS C. S. 2002. Prehistoric Middens and a Cemetery from the Southern Arabian Gulf. In S. Cleuziou, M. Tosi, J. Zarins (eds.), Essays on the Late Prehistory of the Arabian Peninsula, vol. 93. Serie Orientale Roma. Roma: Istituto Italiano per l'Africa e l'Oriente: 169-186.

SALVATORI S. 1996. Death and ritual in a population of coastal food foragers in Oman. In G. E. Afanas'ev, S. Cleuziou, J. R. Lukacs, M. Tosi (eds.), The prehistory of Asia and Oceania. Colloquium XXXII: Trade as a Subsistence Strategy. Post-Pleistocene Adaptations in Arabia and Early Maritime Trade in Indian Ocean. XIII International Congress of Prehistoric and Protohistoric Sciences, vol. Coll. 16. Forli, Italy: Abaco: 205-222.

SANTINI G. 2002. Burial Complex 43 at the Prehistoric Graveyard of Ra's al-Hamra in Northern Oman. In S. Cleuziou, M. Tosi, J. Zarins (eds.), Essays on the Late Prehistory of the Arabian Peninsula, vol. 93. Serie Orientale Roma. Roma: Istituto Italiano per l'Africa e l'Oriente: 147167.

UERPMANN H.P., UERPMANN M., JASIM S. A. (eds.) 2006 a. Funeral Monuments and Human Remains from Jebel al-Buhais. Vol. 1. The Archaeology of Jebel al-Buhais, Sharjah, United Arab Emirates. Tübingen: Department of Culture and Information, Government of Sharjah, U.A.E./Kerns Verlag.

UERPMANN M. 2003. The Dark Millennium - Remarks on the Final Stone Age in the Emirates and Oman. In D. T. Potts, H. Al Naboodah, P. Hellyer (eds.), Proceedings of the First International Conference on the Archaeology of the United Arab Emirates, CD-ROM edition. Trident Press: 73-81.

UERPMANN M., UERPMANN H.-P. 2000. Faunal Remains of Al-Buhais 18: an Aceramic Neolithic site in the Emirate of Sharjah (SE-Arabia) - excavations 1995-1998. In M. Mashkour, H. Buitenhuis, A. L. Choyke, F. Poplin (eds.), Archaeozoology of the Near East. Proceedings of the fourth international symposium on the archaeozoology of southwestern Asia and adjacent areas, vol. IV B, Archaeological Research and Consultancy 32. Oxford: Oxbow: 40-49.

UERPMANN M., UERPMANN H.-P., JASIM S. A. 2000. Stone Age nomadism in SE-Arabia - paleo-economic considerations on the neolithic site of Al-Buhais 18 in the Emirate of Sharjah, U.A.E. Proceedings of the Seminar for Arabian Studies 30: 229-234. 
2006b. Früher Wüstennomadismus auf der Arabischen Halbinsel. In S. R. Hauser (ed.), Die Sichtbarkeit von Nomaden und saisonaler Besiedlung in der Archäologie. Multidisziplinäre Annäherungen an ein methodisches Problem. Mitteilungen des SFB "Differenz und Integration", 9, vol. 21, Orientwissenschaftliche Hefte. Halle/Saale: Orientwissenschaftliches Zentrum der Universität Halle-Wittenberg: 87-103.
VAN GENNEP A. 1986. Übergangsriten (Les rites de passage). Frankfurt, New York: Campus.

VANHAEREN M. 2002. Les fonctions de la parure au Paléolithique supérieur: de l'individu à l'unité culturelle. Doctorate, Université Bordeaux I. 